\title{
METABOLISME LIPOPROTEIN
}

\author{
Edmond L. Jim \\ Bagian Kardiologi dan Kedokteran Vaskular Fakultas Kedokteran \\ Universitas Sam Ratulangi Manado \\ Email: edmondjim@yahoo.com
}

\begin{abstract}
Lipid is a hydropobic substance. Thence, it needs a transporter protein called apoprotein. This lipid together with its apoprotein is called lipoprotein which is needed to deliver lipids to and from body tissues to produce energy. Based on their density, there are six types of lipoproteins: chylomicron, VLDL, IDL, LDL, HDL, and Lp(a). The metabolism of lipoproteins consists of three pathways: the exogenic pathway that produces chylomicron; the endogenic pathway that produces VLDL, IDL, and LDL; and the reverse cholesterol transport that produces HDL.
\end{abstract}

Keywords: lipoprotein, lipid, apoprotein, protein.

\begin{abstract}
Abstrak: Lipid umumnya bersifat hidrofobik, oleh karena itu diperlukan protein pengangkut yang disebut apoprotein. Senyawa lipid bersama apoprotein disebut lipoprotein. Kompleks lipoprotein diperlukan agar lipid dapat disalurkan ke dan dari jaringan tubuh untuk menghasilkan energi. Lipoprotein dapat dibedakan berdasarkan densitas yaitu kilomikron, VLDL, IDL, LDL, HDL, dan Lp(a). Terdapat tiga jalur metabolisme lipoprotein, yaitu: jalur eksogen yang menghasilkan kilomikron; jalur endogen yang menghasilkan VLDL, IDL, dan LDL; dan reverse cholesterol transport yang menghasilkan HDL.
\end{abstract}

Kata kunci: lipoprotein, lipid, apoprotein, protein.

Makanan yang dimakan harus diproses menjadi berbagai produk melalui pencernaan karbohidrat, protein dan lipid, terutama berupa glukosa, asam amino, serta asam lemak dan gliserol. Semua produk hasil pencernaan diproses melalui lintasan masing-masing menjadi produk umum, asetil KoA, yang kemudian dioksidasi secara sempurna lewat siklus asam sitrat. ${ }^{1}$

Kandungan lipid dalam makanan terdiri dari trigliserida, kolesterol, dan fosfolipid; trigliserida merupakan jenis lipid terbanyak. ${ }^{1-3}$ Lemak jenuh (saturated) terdapat pada produk hewani (daging dan susu) sedangkan lemak tak jenuh (unsaturated) pada biji-bijian, kacang, dan minyak sayuran. Sumber kolesterol ialah kuning telur, jeroan, dan produk susu. ${ }^{2}$

Lipid berfungsi sebagai sumber energi; insulator panas di jaringan sub-kutan; cadangan energi (trigliserida); prekursor hormon adrenal dan steroid gonadal serta asam empedu (kolesterol). ${ }^{3}$

Lipid umumnya bersifat hidrofobik; ${ }^{1-3}$ oleh karena itu dibutuhkan suatu pelarut yaitu apoprotein. Senyawa lipid bersama apoprotein disebut lipoprotein. Lipoprotein merupakan partikel berbentuk bola yang berfungsi mentranspor lipid dalam darah, antara lain kolesterol dan trigliserida. ${ }^{4}$

Metabolisme lipoprotein dibagi atas tiga jalur yaitu jalur metabolisme eksogen, endogen, dan jalur reverse cholesterol transport. Masing-masing jalur menghasilkan jenis lipoprotein tertentu dengan fungsi yang spesifik. $^{4}$

\section{JENIS-JENIS LIPID}

Lipid dalam makanan terdiri dari 
trigliserida, fosfolipid, dan kolesterol. Trigliserida tersusun oleh tiga asam lemak yang teresterifikasi ke molekul gliserol. Trigliserida sebagai sumber asam lemak dan membentuk lipid di jaringan adiposa. Trigliserida juga ditranspor sebagai komponen lipoprotein. Trigliserida dihidrolisis dalam jaringan adiposa, dan melepaskan asam lemak bebas yang akan digunakan sebagai sumber energi. ${ }^{2,4}$

Fosfolipid mempunyai struktur yang mirip dengan trigliserida, tetapi pada atom C ketiga dari gliserol terikat gugus fosfat. Fosfolipid merupakan molekul hidrofilik sehingga dapat bercampur pada permukaan pemisah air-lemak. Jenis lipid ini yang membentuk komponen membran dari lipoprotein. ${ }^{1,2}$

Kolesterol merupakan komponen utama membran sel, serta sebagai prekursor hormon steroid, asam empedu dan vitamin D. ${ }^{1,2,5}$ Sumber kolesterol dalam darah yaitu $15 \%$ berasal dari makanan dan $85 \%$ dibuat dari asetil KoA di hati. Kolesterol dikeluarkan dari tubuh ketika dikatabolisme dan disekresi dalam garam empedu, yang akhirnya diekskresi melalui feses. ${ }^{6}$

Dari bermacam-macam lipid, hanya asam lemak bebas (yang berasal dari trigliserida) yang dioksidasi menjadi energi. Trigliserida dikatabolisme, memisahkan asam lemak dan gliserol. Gliserol akan dikonversi menjadi gliseraldehidfosfat kemudian masuk ke siklus Krebs. Oksidasi asam lemak terjadi di mitokondria, dimana asam lemak dipecah menjadi asetil KoA. ${ }^{6}$

\section{LIPOPROTEIN}

Lipoprotein merupakan kompleks makromolekul yang mengangkut lipid hidrofobik (khususnya trigliserida dan kolesterol) dalam cairan tubuh (plasma, cairan interstisial, dan limf) ke dan dari jaringan. $^{1}$

Lipoprotein berbentuk sferis dan mempunyai inti trigliserida dan kolesterol ester, dikelilingi lapisan permukaan yang dibentuk oleh fosfolipid amfipatik dan sedikit kolesterol bebas dengan apoprotein yang terdapat pada permukaan lipoprotein (Gambar 1).

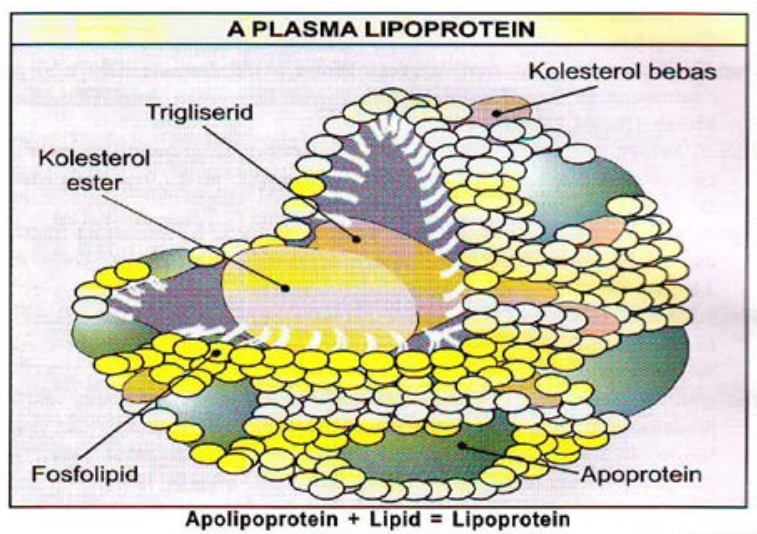

Gambar 1. Bentuk molekul lipoprotein. Sumber: Adam JM, 2010.7

Pada manusia dapat dibedakan 6 jenis lipoprotein, yaitu high density lipoprotein (HDL atau $\alpha$-lipoprotein) sebagai pengangkut kolesterol; very low density lipoprotein (VLDL atau pre $\beta$-lipoprotein) yang berasal dari hati untuk mengeluarkan trigliserida; intermediate density lipoprotein (IDL) yang sebagian besar trigliseridanya sudah dikeluarkan; low density lipoprotein (LDL atau $\beta$-lipoprotein) yang merupakan tahap akhir katabolisme VLDL dimana hampir semua trigliserida telah dikeluarkan; kilomikron yang berasal dari penyerapan trigliserida di usus; dan lipoprotein a kecil [Lp(a)]. ${ }^{1,2,5,7,9}$

\section{Karakteristik lipoprotein dan apo- protein}

Setiap kelas lipoprotein terdiri dari partikel dengan densitas, ukuran, dan komposisi protein yang berbeda-beda. Densitas lipoprotein ditentukan oleh jumlah lipid per partikel (Gambar 2). Kolesterol HDL merupakan lipoprotein yang paling kecil dan padat, sedangkan kilomikron dan VLDL yaitu lipoprotein yang paling besar dan kurang padat. Umumnya trigliserida plasma ditranspor dalam kilomikron atau VLDL, dan kebanyakan kolesterol plasma diangkut sebagai kolesterol teresterifikasi dalam LDL dan HDL. ${ }^{1,7,9}$ 


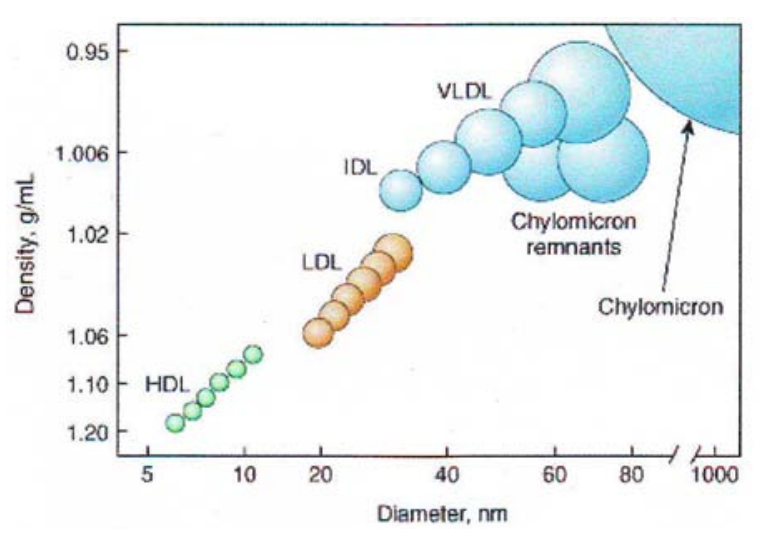

Gambar 2. Jenis lipoprotein berdasarkan densitas. Sumber: Adam JM, 2010. ${ }^{7}$

\section{Apoprotein}

Apoprotein mengaktifkan enzim penting dalam metabolisme lipoprotein dan berfungsi sebagai ligan untuk reseptor permukaan sel. ${ }^{2,5}$

ApoA-I ialah apoprotein utama dari HDL, dan juga terdapat di kilomikron. Jenis ini merupakan apoprotein terbanyak dalam serum, dan kofaktor untuk lecithin cholesterol acyltransferase (LCAT). ${ }^{8}$ ApoA-I diproduksi oleh usus dan hati dan juga ditemukan pada permukaan remnan lipoprotein selama lipolisis. ${ }^{2,8,10}$ ApoA-II merupakan apoprotein HDL terbanyak kedua setelah ApoA-I. ApoA-IV berikatan dengan kilomikron. ApoA-V menjadi aktif di dalam hepatosit dan juga terdapat dalam HDL. ${ }^{1,2,9}$

ApoB merupakan protein utama dari kilomikron, VLDL, IDL, dan LDL. ApoB tidak berpindah dari satu lipoprotein ke lipoprotein lain. Hati mensintesis apoB-100 sedangkan usus apoB-48, yang diturunkan dari gen yang sama oleh mRNA editing. ${ }^{11-14}$

Terdapat 3 jenis apolipoprotein dari seri-C (apoC-I, apoC-II, dan apoC-III) yang berperan dalam metabolisme lipoprotein kaya trigliserida. ApoC merupakan protein dengan berat molekul rendah yang merupakan kofaktor untuk enzim lipase. ${ }^{2,8,9}$

ApoE terdapat pada kilomikron, VLDL, dan IDL, dan berperan penting dalam metabolisme partikel yang kaya trigliserida. Terdapat 3 jenis apoE yaitu: apoE II-IV yang diproduksi dari gen alel.
ApoE-II tidak mengandung ligan fungsional dari reseptor LDL. ${ }^{2,8,9}$

\section{RESEPTOR LDL}

Reseptor LDL merupakan glikoprotein yang terdapat pada permukaan hampir semua sel terutama hepatosit. Reseptor LDL berfungsi dalam pengambilan lipoprotein yang mengandung apoB dan apoE, termasuk LDL, remnan kilomikron, VLDL, remnan VLDL, dan HDL. Umumnya HDL yang kurang apoE tidak berinteraksi dengan reseptor LDL. ${ }^{1,2}$

Sel-sel dapat menerima kolesterol plasma yang diambil dari lipoprotein melalui reseptor LDL. ApoB-100 dan apoE pada permukaan lipoprotein mengikat reseptor LDL. ${ }^{1,2}$ Protein Lp(a) ditemukan sebagai disulfide bridged dimer dengan apoB-100 dalam LDL. ${ }^{8}$ Kompleks lipoprotein yang berikatan dengan reseptor LDL akan dibawa ke membran sel membentuk vesikel intrasel, masuk ke dalam sitoplasma, kemudian terjadi pemisahan lipoprotein dan reseptor LDL. Lipoprotein akan didegradasi dalam lisosom dan reseptor LDL kembali ke permukaan sel. ${ }^{1,2}$ Reseptor LDL disintesis dalam retikulum endoplasma. Mutasi dalam area ini akan mengganggu fungsi reseptor LDL dalam metabolisme lipoprotein dan menyebabkan terjadinya hiperkolesterolemia familial. ${ }^{2}$

LDL berinteraksi dengan reseptor LDL di permukaan sel. Kompleks ini masuk ke dalam sel dan diinternalisasi. Coated vesicle melepaskan clathrin dan menjadi endosom, yaitu tempat lipoprotein dan reseptor dipisahkan. Reseptor kembali ke permukaan sel, dan lipoprotein didegradasi. Reseptor baru disintesis dalam retikulum endoplasma kasar dan ditranspor ke permukaan sel (Gambar 3). ${ }^{2}$

\section{METABOLISME LIPOPROTEIN}

Metabolisme lipoprotein dibagi atas tiga jalur yaitu jalur metabolisme eksogen, endogen, dan jalur reverse cholesterol transport. Kedua jalur pertama berhubungan dengan metabolisme kolesterol- 
LDL dan trigliserida, sedangkan jalur reverse cholesterol transport dikhususkan ke metabolisme kolesterol-HDL. ${ }^{5,7,9}$

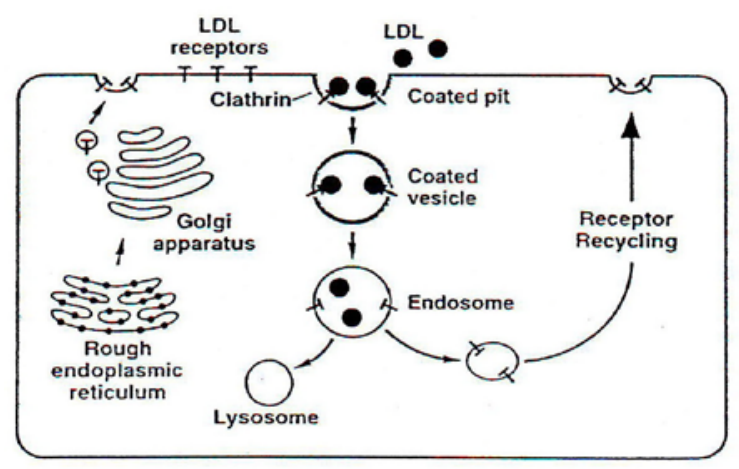

Gambar 3. Jalur kerja reseptor LDL. Sumber: Semenkovich CF et al., 2011. ${ }^{2}$

\section{Jalur metabolisme eksogen}

Dalam makanan, lipid yang terbanyak yaitu trigliserida serta sejumlah kecil fosfolipid, kolesterol, dan ester kolesterol. Selain dari makanan, kolesterol juga berasal dari hati. Lipid dalam usus yang berasal dari makanan disebut lipid eksogen. Dalam lambung, lipid mengalami emulsifikasi oleh empedu menjadi parti-kel lebih kecil sehingga enzim pencernaan dapat bekerja. Trigliserida dihidrolisis di dalam usus oleh lipase pankreas dan lipase usus menjadi asam lemak bebas dan monogliserida. Bersama empedu, asam lemak bebas dan monogliserol dalam bentuk miselus masuk ke brush border enterosit untuk diabsorbsi. Empedu dilepas kembali untuk didaur ulang dalam proses pengangkutan., ${ }^{3,9,15}$

Dalam enterosit, asam lemak bebas akan diubah lagi menjadi trigliserida, sedangkan kolesterol akan mengalami esterifikasi menjadi kolesterol ester; keduanya bersama dengan fosfolipid dan apoprotein B-48 akan membentuk lipoprotein yang disebut kilomikron nascent. , $^{2-9}$

Kilomikron diakumulasi di apparatus Golgi dan disekresi ke sisi lateral enterosit, masuk ke saluran limf dan akhirnya melalui duktus torasikus akan masuk ke dalam aliran darah. Kilomikron nascent memiliki
apoB-48, apoA-1, apoA-IV, dan mendapat apoC-II dan apoE dari HDL di kelenjar limf dan darah. Trigliserida dalam kilomikron akan di hidrolisis oleh enzim lipoprotein lipase (LPL, diaktifkan oleh apoC-II) yang berasal dari endotel kapiler di jaringan adiposa, jantung, serta otot rangka, dan melepaskan asam lemak bebas (free fatty acid, FFA). Asam lemak bebas yang dilepaskan diambil oleh miosit dan adiposit, dioksidasi untuk menghasilkan energi atau diesterifikasi dan disimpan sebagai trigliserida dalam jaringan adiposa. Bila asam lemak bebas terdapat dalam jumlah besar, sebagian akan diambil oleh hati menjadi bahan pembentuk trigliserida. Kilomikron yang kehilangan sebagian besar trigliseridanya akan menjadi kilomikron remnan yang mengandung kolesterol ester dan akan dibawa ke hati melalui ligan apoE (Gambar 4). ${ }^{2,3,9}$

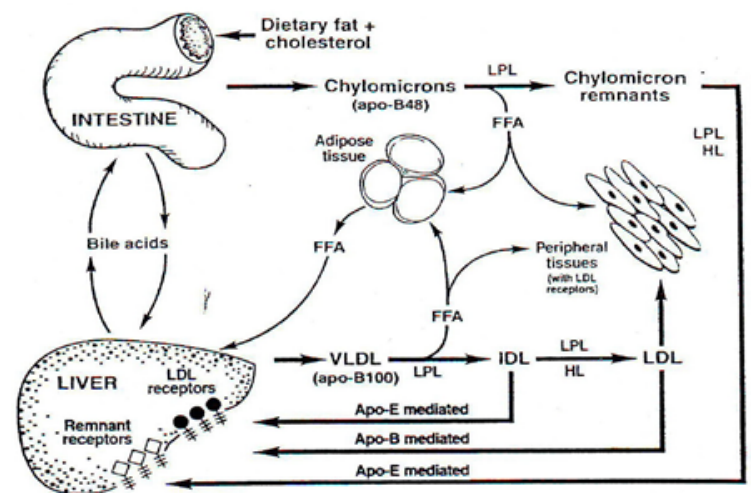

Gambar 4. Jalur metabolism kilomikron. Sumber: Semenkovich CF et al., 2011. ${ }^{2}$

Remnan kilomikron kaya akan kolesterol ester, dan merupakan komponen lipid utama pada lesi aterosklerosis, yang dapat masuk ke subendotel dan selanjutnya difagositosis oleh makrofag. ${ }^{5}$ Remnan kilomikron dibersihkan dari plasma oleh reseptor lipoprotein dan akhirnya diambil dan didegradasi oleh hepatosit. Pembersihan plasma termasuk sekuestrasi dalam celah Disse oleh heparan sulfat proteoglikan, keterlibatan LPL dalam proses lebih lanjut dan mengikat sel permukaan, dan 
internalisasi yang dimediasi oleh heparan sulfat proteoglikan. ${ }^{2,5,8}$

\section{Jalur metabolisme endogen}

Deposit lipid dalam hepatosit dimetabolisme menjadi trigliserida dan kolesterol ester. ${ }^{5}$ Packaging trigliserida hati dengan komponen lain VLDL nascent dimediasi oleh enzim microsomal triglyceride transfer protein (MTP). Trigliserida dan fosfolipid yang digunakan untuk pembentukan VLDL disintesis dalam retikulum endoplasma, selanjutnya masuk ke aparatus Golgi, menyatu dengan permukaan lumen hepatosit, melepaskan VLDL ke celah Disse, dan masuk ke kapiler jaringan adiposa dan otot sebagai lipoprotein VLDL nascent dengan apoB-100. ${ }^{9}$

Lipoprotein VLDL terdiri dari 85-90\% lipid (55\% trigliserida, 20\% kolesterol, $15 \%$ fosfolipid) dan $10-15 \%$ protein., Apoprotein apoB-100 merupakan bentuk hepatik dari apoB. Selain itu, VLDL juga berisi apoE dan apoCs yang didapat dari HDL dalam sirkulasi. Trigliserida VLDL akan dihidrolisis oleh enzim lipoprotein lipase (LPL) dan hepatic lipase (HL) menjadi asam lemak bebas. Lipoprotein VLDL dikonversi ke IDL yang hanya mengandung apoB dan apoE. Lipoprotein IDL dapat diambil oleh reseptor LDL (LRP, low density lipoprotein receptorrelated proteins) di hati. Lipoprotein IDL dengan apoE normal dihidrolisis oleh LPL dan HL menjadi LDL. ${ }^{2,16,17}$

Lipoprotein LDL merupakan lipoprotein yang paling banyak mengandung kolesterol dan merupakan produk akhir dari hidrolisis VLDL yang dimediasi lipase. Sekitar 70\% kolesterol plasma total terdapat di dalam LDL. Lipoprotein LDL terdiri dari 75\% lipid (35\% kolesterol ester, 10\% kolesterol bebas, $10 \%$ trigliserida, $20 \%$ fosfolipid) dan $25 \%$ protein. ${ }^{1,2}$

Sebagian kolesterol LDL akan dibawa ke hati dan jaringan steroidogenik lainnya seperti kelenjar adrenal, testis, dan ovarium yang mempunyai reseptor kolesterol-LDL, dimediasi oleh apoB-100. Lipoprotein LDL didegradasi di hepatosit dan akan melepaskan kolesterol yang digunakan untuk biosintesis VLDL dan sintesis membran atau menjadi prekursor biosintesis asam empedu. Asam empedu dan kolesterol bebas dibawa ke kantong empedu. Sebagian kecil kolesterol-LDL masuk ke subendotel, mengalami oksidasi, ditangkap oleh reseptor scavenger-A (SR-A) makrofag, dan difagositosis oleh makrofag yang akan menjadi sel busa (foam cell). Makin banyak kadar kolesterol-LDL dalam plasma, maka makin banyak yang akan mengalami oksidasi dan ditangkap oleh makrofag. Jumlah kolesterol yang akan teroksidasi tergantung dari kadar kolesterol yang terkandung dalam LDL (Gambar 5). ${ }^{1,7,8,11}$

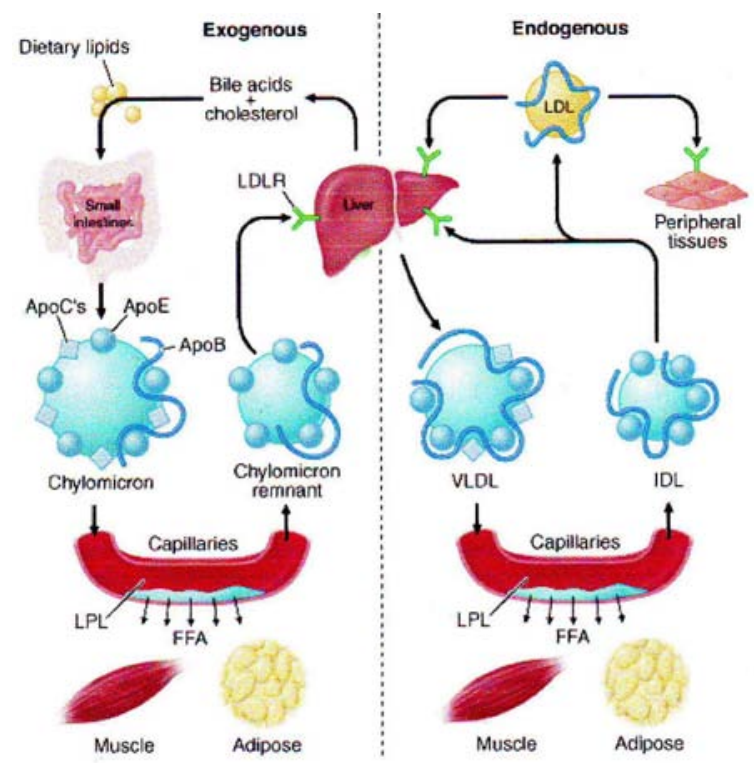

Gambar 5. Jalur metabolisme eksogen dan endogen. Sumber: Rader DJ dan Hobbs HH, $2008 .^{9}$

\section{Metabolisme HDL dan reverse cholesterol transport}

HDL merupakan partikel paling kecil yang disintesis dalam hati dan usus, dan mengandung $50 \%$ lipid dan $50 / \%$ protein, dengan apoprotein apoA-I dan apoA-II, dimana HDL dapat dibagi berdasarkan densitasnya menjadi HDL2 dan HDL3., ${ }^{1,2}$ Hepatosit dan enterosit dapat mengeluarkan kolesterol dari tubuh melalui 
saluran empedu dan usus. Di hati, kolesterol diekskresi ke empedu secara langsung atau sesudah konversi ke asam empedu. Kolesterol dalam sel-sel perifer ditranspor dari membran sel perifer ke hati dan usus melalui proses reverse cholesterol transport yang difasilitasi oleh HDL. ${ }^{1,8,10}$

Lipoprotein HDL nascent disintesis dalam usus dan hati. HDL dilepaskan sebagai partikel kecil yang miskin kolesterol, berbentuk gepeng, dan mengandung apoA-I, apoC, dan apoE. HDL nascent akan mengambil kolesterol dari makrofag; untuk itu, kolesterol di bagian dalam makrofag harus dibawa ke permukaan membran makrofag oleh transporter adenosine triphosphate-binding cassette A-1 (ABCA-1). Proses ini menghasilkan bentuk cakram HDL dan mendapat tambahan kolesterol unesterified dari perifer. Dalam HDL, kolesterol diesterifikasi oleh lecitin-cholesterol acyltransferase (LCAT) menjadi kolesterol ester. Kolesterol ester yang lebih hidrofobik akan pindah ke inti HDL, dan HDL yang telah mendapat lebih banyak kolesterol ester menjadi bentuk sferis. Tambahan apoprotein dan lipid ditransfer ke HDL dari permukaan kilomikron dan VLDL selama lipolisis. ${ }^{1,5,7,9,10}$

Kolesterol HDL ditranspor ke hepatosit secara langsung dan tidak langsung. Kolesterol ester HDL ditransfer ke lipoprotein yang berisi apoB (VLDL, IDL, LDL) untuk pertukaran dengan trigliserida oleh cholesterol ester transfer protein (CETP) (Gambar 6). Kolesterol ester ditranspor ke hati setelah konversi VLDL ke IDL dan ke LDL, kemudian diambil oleh reseptor LDL. Jalur ini bekerja tidak langsung karena transfer kolesterol ester lipoprotein-apoB menghasilkan partikel kaya kolesterol yang mungkin diambil oleh sel busa dalam plak aterosklerosis sebelum dibersihkan oleh hati ${ }^{5}$ dan dibersihkan dari sirkulasi melalui endositosis yang dimediasi reseptor LDL. ${ }^{9}$ HDL kolesterol dapat juga diambil secara langsung oleh hepatosit melalui scavenger receptor class $B I$ (SR-BI), yaitu reseptor permukaan sel yang memediasi transfer selektif dari lipid ke dalam sel. ${ }^{1,2,5,7,9}$

Lipoprotein HDL mengalami remodeling dalam plasma oleh berbagai protein transfer lipid dan lipase. Protein transfer fosfolipid berefek pada transfer fosfolipid dari lipoprotein lain ke HDL. Setelah pertukaran lipid yang dimediasi CETP (Gambar 6, 7), HDL yang kaya trigliserida menjadi substrat yang lebih baik dari lipase hati, yang menghidrolisis trigliserida dan fosfolipid untuk menghasilkan smaller HDL. Enzim yang berperan yaitu endothelial lipase menghidrolisis fosfolipid HDL, dan menghasilkan smaller HDL yang dikatabolisme lebih cepat. Remodeling HDL memengaruhi metabolisme, fungsi, dan konsentrasi HDL plasma. $^{9}$

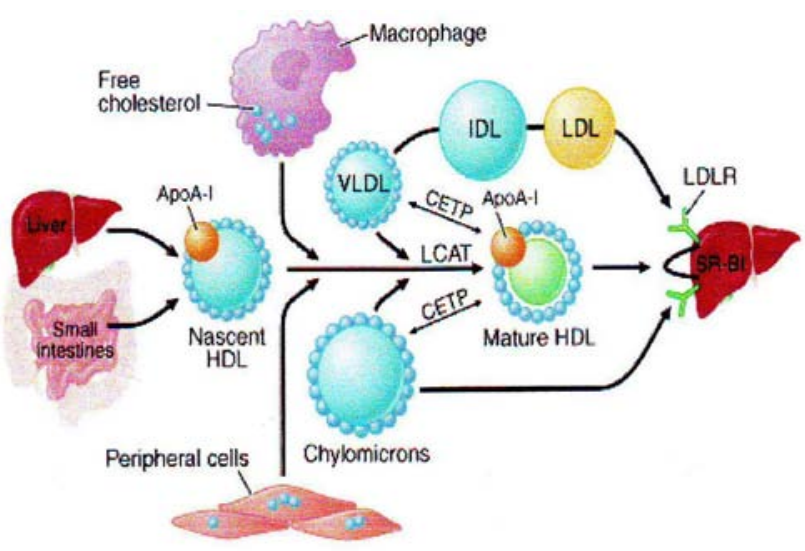

Gambar 6. Metabolisme HDL dan reverse cholesterol transfer. Sumber: Rader DJ dan Hobbs HH, 2008. ${ }^{9}$

Reverse cholesterol transport memerlukan HDL. HDL mengantar kolesterol ke hati melalui tiga mekanisme, yaitu: 1) Sebagian besar kolesterol ester HDL ditransfer dari HDL ke VLDL, IDL, LDL oleh cholesterol ester transfer protein (CETP), dan VLDL, IDL, dan LDL remnan diambil oleh hati. Secara tidak langsung, HDL mengantar kolesterol ester ke hati. 2) HDL dapat terikat ke reseptor SR-BI, yang memfasilitasi pemindahan langsung kolesterol dari HDL oleh hati. 3) Reseptor hepatosit dapat berinteraksi dengan HDL untuk memindahkan HDL dari plasma (Gambar 7). ${ }^{1}$ 


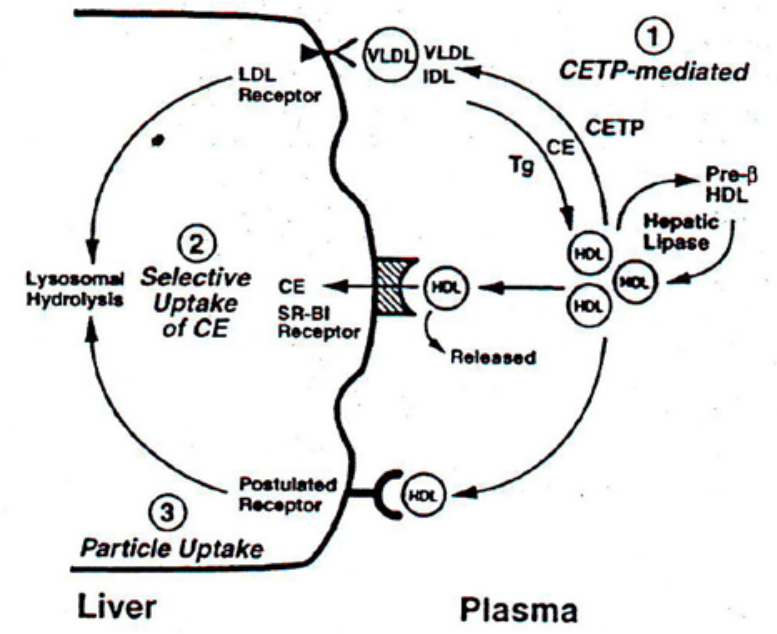

Gambar 7. Jalur reverse cholesterol transfer. Sumber: Mahley RW, 2001. ${ }^{1}$

\section{Metabolisme Lp(a)}

Lipoprotein Lp(a) mempunyai ukuran densitas di antara LDL dan HDL. Sumber Lp(a) belum diketahui. Lp(a) menyerupai LDL dalam komposisi lipid dan memiliki apoB-100 dan mendapat apo(a). ApoB-100 merupakan protein utama dari Lp(a). Rasio apo(a) dan apoB-100 dalam Lp(a) 1:1. ${ }^{18}$

Nilai normal Lp(a) dalam darah $<30$ mg/dL. Meningkatnya Lp(a) dihubungkan dengan risiko penyakit jantung coroner dan telah dideteksi dalam lesi aterosklerosis. ${ }^{1}$

\section{SIMPULAN}

Lipid bersifat hidrofobik, oleh karena itu diperlukan protein pengangkut yang disebut apoprotein. Senyawa lipid bersama apoprotein disebut lipoprotein. Lipoprotein dapat dibedakan berdasarkan densitas yaitu kilomikron, VLDL, IDL, LDL, HDL, dan Lp(a). Metabolisme lipoprotein dibagi atas tiga jalur yaitu jalur eksogen yang menghasilkan kilomikron, jalur endogen yang menghasilkan VLDL, IDL, LDL, dan metabolisme HDL yang menghasilkan HDL.

\section{DAFTAR PUSTAKA}

1. Mahley RW. Biochemistry and physiology of lipid and lipoprotein metabolism. In:
Becker KL, editor. Principles and Practice of Endocrinology and Metabolism. Philadelphia: Lippincott William \& Wilkins, 2001; p.1503-50.

2. Semenkovich CF, Goldberg AC, Goldberg IJ. Disorders of lipid metabolism. In: Melmed S, Polonsky KS, Larsen PR, Kronenberg HM, editors. Williams Textbook of Endocrinology. Philadelphia: Elsevier Saunders, 2011; p.1633-74.

3. Botham KM, Mayes PA. Bioenergetika dan metabolisme karbohidrat serta lipid. In: Murray RK, Granner DK, Mayes PA, Rodwell VW, editors. Biokimia Harper (Edisi 27). Jakarta: EGC, 2012; p.95-249.

4. Kovar J, Havel RJ. Sources and properties of triglyceride-rich lipoproteins containing apoB-48 and apoB-100 in postprandial blood plasma of patients with primary combined hyperlipidemia. J Lipid Res. 2002;43:1026-34.

5. Semenkovich CF. Disorders of lipid metabolism. In: Goldman L, Ausiello D, editors. Cecil Medicine (Twentythird Edition). Philadelphia: Saunders Elsevier; 2007.

6. Welty FK, Lichtenstein AH, Barrett PHR, Dolnikowski GG, Schaefer EJ. Human apolipoprotein (apo) B-48 and apoB-100 kinetics with stable isotopes. Arterioscler Thromb Vasc Biol. 1999;19:2966-74.

7. Adam JM. Dislipidemia. In: Sudoyo AW, Setiyohadi B, Alwi I, Simadibrata M, Setiati S, editors. Buku Ajar Ilmu Penyakit Dalam. Jakarta: Interna Publishing, 2010; p.1984-1992.

8. Malloy MJ, Kane JP. Disorders of lipoprotein metabolism. In: Gardner DG, Shoback D, editors. Greenspan's Basic \& Clinical Endocrinology (Eighth Edition). New York: McGraw Hill, 2007; p.770-795.

9. Rader DJ, Hobbs HH. Disorders of lipoprotein metabolism. In: Fauci AS, Braunwald E, Kasper DL, Hauser SL, Longo DL, Jameson JL, Loscalzo J, editors. Harrison's Principles of Internal Medicine. New York: McGrawHill Medical, 2008; p.2416-28.

10. Chetiveaux M, Ouguerram K, Zair $Y$, Maugere $P$, Falconi I, Nazih $\mathbf{H}$, et al. New model for kinetic studies of HDL metabolism in humans. Eur $\mathrm{J}$ Clin 
Invest. 2004;34:262-7.

11. Watts GF, Moroz P, Barrett PHR. Kinetics of very-low-density lipoprotein apolipoprotein B-100 in normolipidemic subjects: Pooled analysis of stable-isotope studies. Metabolism. 2000;49:1204-10.

12. Ginsberg HN, Le NA, Gibson JC. Regulation of the production and catabolism of plasma low density lipoproteins in hypertriglyce-ridemic subjects. Effect of weight loss. J Clin Invest. 1985;75:614-23.

13. Burnett JR, Barrett PH. Apolipoprotein B metabolism: Tracer kinetics, models, and metabolic studies. Critical Rev Clin Lab Sci. 2002;39:89-137.

14. Adiels M, Packard C, Caslake MJ, Stewart P, Soro A, Westerbacka J, et al. A new combined multicompartmental model for apolipoprotein B-
100 and triglyceride metabolism in VLDL subfractions. J Lipid Res. 2005;46:58-67.

15. Guyton AC, Hall JE. Metabolisme lipid. In: Guyton AC, Hall JE, editors. Buku Ajar Fisiologi Kedokteran (Edisi 11). Jakarta: EGC, 2006; p.882-94.

16. Parhofer KG, Barrett PHR. Thematic review series: Patient-oriented research. What we have learned about VLDL and LDL metabolism from human kinetics studies. J Lipid Res. 2006;47:1620-30.

17. Marsh JB, Welty FK, Lichtenstein AH, Lamon-Fava S, Schaefer EJ. Apolipoprotein B metabolism in humans: Studies with stable isotopelabeled amino acid precursors. Atherosclerosis. 2002;162:227-44.

18. Ginter E, Simko V. Enigmatic lipoprotein (a) and cardiovascular disease. Bratisl Lek Listy. 2010;111:570-3. 